\title{
Effect of Solidago Eradication Methods on Soil Invertebrates - Preliminary Studies
}

\section{Peliyagodage Chathura Dineth Perera1, Iwona Gruss², Jacek Twardowski²*, Magdalena Szymura ${ }^{1}$}

${ }^{1}$ Institute of Agroecology and Plant Production, Wrocław University of Environmental and Life Sciences, Grunwaldzki Sq 24a, 50-363 Wrocław, Poland

${ }^{2}$ Department of Plant Protection, Wrocław University of Environmental and Life Sciences, Grunwaldzki Sq 24a, 50-363 Wrocław, Poland

Received: 12 February 2021

Accepted: 1 June 2021

\begin{abstract}
Evaluation of belowground impacts of methods of invasive plant eradication, especially in the context of grassland restoration, gives information about rates of ecosystem restoration. This study tested the hypotheses: (1) the method of seed application and plant species diversity used in grassland restoration impacts on mesofauna communities, (2) the mowing regime influences the abundance of soil invertebrates. A two-factorial experiment using: (1) different methods of seed introduction and composition (sowing the seed mixture of pasture grasses, pasture grasses with legumes, seed collected from a semi-natural meadow, and application of fresh hay), and (2) different frequencies of mowing (once, twice and three times per year), was established during the restoration of grassland which had been invaded by Solidago plants. The experiment was designed as a randomized complete block design with four replications. The results were revealed that mowing intensity decreased the abundance of Chilopoda and Isopoda, while the introduction of fresh hay used in grassland restoration positively affected nematodes. Also, the biological soil quality index based on arthropods (QBS-ar) indicated a decrease of soil biological quality in stands mown 2 and 3 times in comparison to mowing once. Further studies are needed to investigate the soil mesofauna dynamics exposed by mowing, and plant diversity.
\end{abstract}

Keywords: biological invasions, grassland restoration, Solidago eradication, soil mesofauna

\section{Introduction}

Plant invasions severely affect the size and species composition of both native plant and animal communities. It can be caused through disruption of

*e-mail: jacek.twardowski@upwr.edu.pl biotic interactions or changes in abiotic ecosystem characteristics [1-2]. North American-originated Solidago spp., commonly called goldenrods, is one of the most significant invasive alien plants in Central Europe [3]. Due to prolific vegetative propagation, Solidago species form dense stands that decrease and alter the biodiversity of plants [4-5] as well as arthropods, e.g. pollinators or coleopterans [6-7]. Moreover, these invasive plants alter the physico-chemical and biological 
properties of soil, which causes a moderate effect on mesofaunal diversity, mainly concerning Collembola and Nematoda community composition [8-9] and soil microbial communities [10]. Shifts in the species composition of different organisms can occur through changes in habitat structure and abiotic properties of the soil [8]. However, the ecological consequences of a strong expansion of invasive plants, including Solidago on invertebrates, are not yet well understood, especially in relation to soil mesofauna.

Soil mesofauna are enormously diverse and play a decisive role in ecosystem functioning. They are common, abundant and functionally important in most ecosystems [11]. All soil organisms are responsible for nutrient cycling, formation of organic matter, soil structure and many other physical properties, but such groups as earthworms, nematodes and arthropods play a significant role in the majority of soil processes. It is understandable that the presence of plants is one of the important factors influencing their occurrence. Moreover, mesofauna respond relatively quickly to any changes in the soil environment and are commonly used as bioindicators of biological soil quality [12-13]. All of them are known for their sensitivity to disturbances associated with agriculture, including the disappearance or simplification of ground cover [14-15].

According to Weidlich et al. [16], primarily, prescribed fire and mowing followed by hand-pulling, cutting and harrowing were the most frequent nonchemical interventions used for controlling invasive plant species during ecological restoration. The chemical application method (glyphosate spraying) is also common. In recent studies, possibilities of restoration of Solidago-invaded lands were used individually or by the combination of multiple forms of control strategies such as grazing, mowing, manual removal, periodic flooding, scalping, rototilling, different seeding methods, and the use of herbicides [17-18]. In this preliminary study we analyzed the abundance of different mesofauna organisms collected from an invasive Solidago stand and subjected to various methods of restoration. We tested the following hypotheses: (1) the method of seed application, and plant species diversity used in grassland restoration have an impact on mesofauna communities, (2) the mowing regime influences the abundance of soil invertebrates.

\section{Material and Methods}

\section{Study Site}

The experiment was established in Wroclaw, Poland

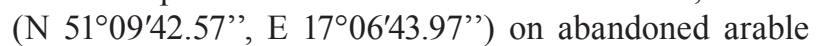
land, now dominated by the invasive North American Solidago species ( $S$. gigantea Alton and $S$. canadensis Linnaeus). The study site was located at an altitude of $118 \mathrm{~m}$ a.s.l. in a small river valley surrounded by suburban buildings and extensively used meadows. The mean annual temperature in the region is $9^{\circ} \mathrm{C}$ and mean annual precipitation is $578.2 \mathrm{~mm}$ per year (data for period 1968-2019). The soil type is Anthropic Regosol, loamy sand texture.

\section{Experimental Design}

The field experiment concerning Solidago species eradication was established in April 2020, with five various methods of seed introduction and composition. Three different seed mixtures were sowed: grasses $(\mathrm{G})$, grasses with legumes (L), seeds collected from a semi-natural meadow (M). Another method of seed application was spreading of fresh hay obtained from high-biodiversity meadow (F). Control (C) was the plots without seed application. The species composition of seeds mixtures, as well as fresh hay is presented in Supplementary Table S1. Second factor of the experiment were different mowing frequencies: once (in June), two times (in June and August), and three times (in June, August and September). The experiment was arranged in a $5 \times 3$ factorial completely randomized design with four replications. In total, 60 plots, arranged

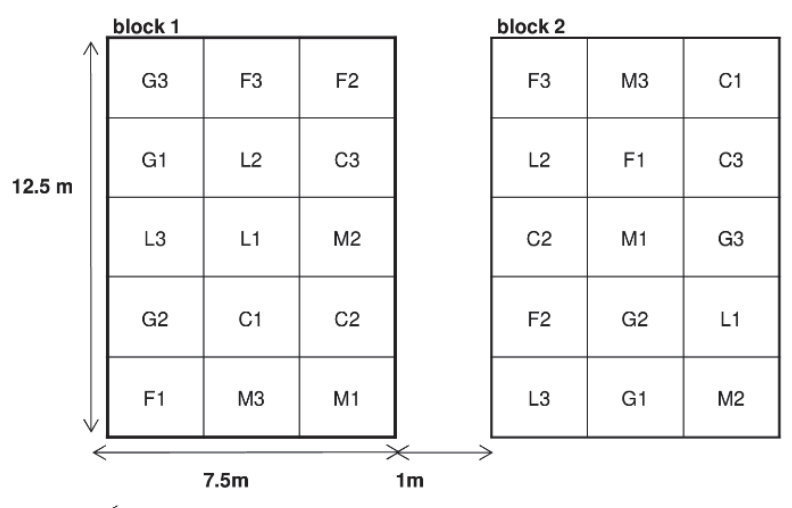

block 3
\begin{tabular}{|c|c|c|}
\hline C1 & F 2 & C2 \\
\hline F1 & G2 & M3 \\
\hline G1 & M2 & G3 \\
\hline M1 & L2 & L1 \\
\hline F3 & L3 & C 3 \\
\hline
\end{tabular}

block 4
\begin{tabular}{|c|c|c|}
\hline G1 & G3 & L1 \\
\hline M2 & G2 & L3 \\
\hline F1 & C2 & F2 \\
\hline M3 & F 3 & M1 \\
\hline C3 & L2 & C 1 \\
\hline
\end{tabular}

\section{$33 m$}

Fig. 1. Plan of the experiment. Abbreviations: F - fresh hay, M - meadow seed mixture, $\mathrm{G}$-grass seeds, L - grasses with legumes, $\mathrm{C}-$ control, 1 - mowing one time per year, 2 - mowing two times per year, 3 - mowing three times per year. 
in four blocks located at a distance of $1 \mathrm{~m}$ from each other, were established. The size of every plot was $2.5 \times 2.5 \mathrm{~m}$, and thus the whole experiment covered a rectangle of $12.5 \times 33 \mathrm{~m}$. The plan of the experiment is presented in Fig. 1.

The observations were performed on plots sized $2 \times 2 \mathrm{~m}$, and therefore the distance between observation plots was $1 \mathrm{~m}$. The experiment was established on abandoned arable land, covered by a dense Solidago stand. Before seed and fresh hay application, the area was mown, and biomass was removed from the experiment site. Next, soil was prepared using a power harrow and compacted with a roller. The plots were mown according to the planned scheme once, twice and three times per year.

\section{Data Collection and Processing}

Soil was sampled with the use of a circular sampler of $10 \mathrm{~cm}$ diameter from the depth of $10 \mathrm{~cm}$. One sample was taken from the center of each plot in September 2020, and so 60 samples were taken altogether. Then soil samples were illuminated in Tullgren funnels (light bulb $25 \mathrm{~W}$ ) for 24 hours. Soil invertebrates extracted from the soil were kept in $75 \%$ ethyl alcohol. They were identified to different taxa which are used for the determination of QBS-ar [19]. Also, other taxa (not arthropods) were counted. The abundance of the taxa identified in the study is presented in Supplementary Table S2. The principle of the QBS-ar index (biological soil quality index based on arthropods) was used to evaluate the traits of sampled arthropods according to their specialization to edaphic life. The maximal number of scores for one taxa is 20 (e.g. Pseudoscorpiones or Acari), while the minimal number is 1 (e.g. adults of holometabolous insects). Some arthropods (mainly Collembola) needed to be accessed according to certain traits. The scores associated with each taxa are also included in Supplementary Table S2. The sum of EMI (Ecomorphological index) scores was counted in each sample. The QBS-ar index is the mean from those sums within certain treatments.

\section{Statistical Analysis}

Statistical analysis was done using the ScheirerRay-Hare test, which is a nonparametric test used for a two-way factorial design. Post-hoc tests were done using Dunn [20] Kruskal-Wallis multiple comparison and p-values adjusted with the Benjamini-Hochberg method for each significant factor using $\mathrm{R}$ software. The values of QBS-ar had normal distribution. Therefore, for those data ANOVA was used.

\section{Results}

In total, 11825 specimens of soil fauna were collected (Supplementary Table S2). The high number

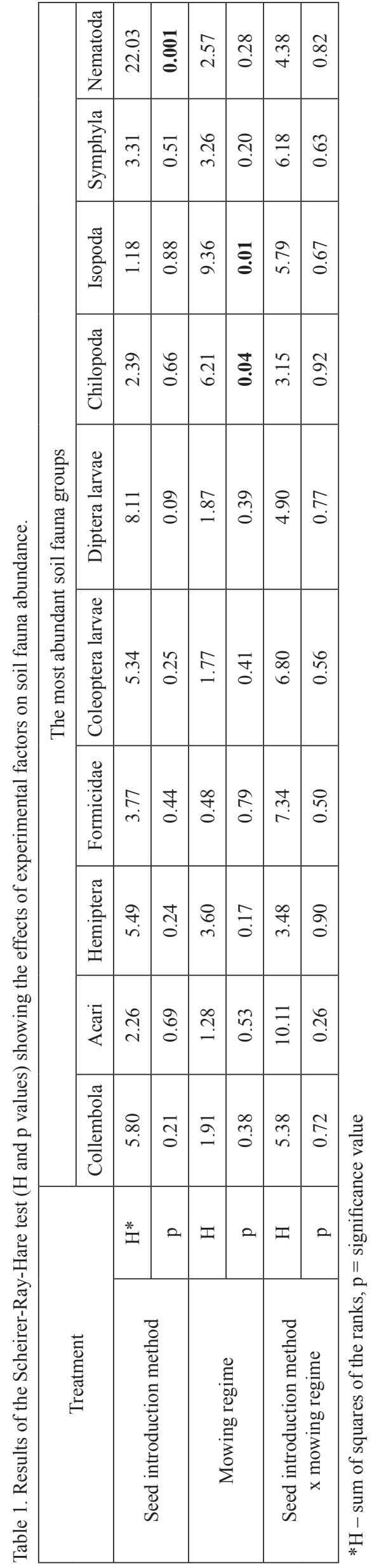


of soil organisms allows analysis of the effects of experimental factors. When considering the abundance of the fauna in general, the highest number of individuals was presented for Collembola (67.37\%), Acari $(23.26 \%)$, and Nematoda (4.42\%). The number of remaining mesofauna was less than $1 \%$. The abundance of the most numerous ten taxa was analyzed, while the number of each of this group was higher than 40 .

The results of the Scheirer-Ray-Hare test showed that there were significant effects of the seed introduction method and mowing regime on selected taxa. Additionally, there were no interactive effects of the seed composition and introduction method and mowing regime for soil fauna abundance (Table 1). Considering the mowing regime, significant effects were found on Isopoda and Chilopoda abundance $(\mathrm{p}=0.04$ and $\mathrm{p}=0.01$, respectively). The average number of Isopoda individuals decreased with increasing mowing regime (the lowest numbers were in stands mown twice a year and the highest in stands mown once per year). For Chilopoda, the post hoc test did not show significant differences between treatments (Fig. 2).

Considering the seed composition and introduction method, only Nematoda differed significantly between treatments $(\mathrm{p}=0.001)$. The average number of Nematoda was higher in the fresh hay application method in comparison to the remaining treatments (Fig. 3).

For QBS-ar index calculation, the abundance of all taxa was taken into account (Supplementary Table S2). QBS-ar varied from 80 to 105 in different treatments (Fig. 4). It was found that mowing significantly affects the QBS-ar value, which indicates significant effects of mowing on biological soil quality $(p=0.03)$. The value of the index was significantly higher in the plots mown once in comparison to plots mown two or three times. Thus, there was a similar trend to Isopoda abundance. Considering the seed composition and introduction method (Fig. 4a), there was no significant effect observed $(\mathrm{p}=0.13)$.

\section{Discussion}

Generally, invasive plants can cause negative impacts on both native biodiversity and ecosystem functioning, including productivity, nutrient cycling, and soil organic matter [21-22]. Therefore it is clear that the consequence may also apply the occurrence of soil organisms. Van Hengstum et al. [2], synthesized 56 studies that compared invaded vs. non-invaded habitats. They estimated that invaded habitats have a median of $29 \%$ lower abundance and 17\% lower species richness compared with non-invaded habitats. Several other case studies also reported significant changes in arthropod abundance following plant invasions [23]. The ecological consequences of plant invasion on soil biota have been much less studied to soil mesofaunal taxa. In riparian wet meadows this problem was reported by Sterzyńska et al. [8]. For the described reasons it is expected that invasive plants, especially those as expansive as goldenrods, will significantly alter the abundance and species structure of various mesofauna representatives, and treatments restoring the natural appearance of a given surface will also have a positive effect on soil fauna.

There is therefore a need for action to reduce the importance of plant invasions. The removal of aboveground biomass by grazing or mowing could be beneficial for grassland biodiversity [24]. Mowing is widely used as a restoration method to replace invasive plants [25]. In our experiment, after one season we found the effect of mowing frequency on 2 from 10 analysed invertebrates groups. Only Chilopoda and Isopoda were significantly negatively affected by increased mowing intensity. The QBS-ar index, which
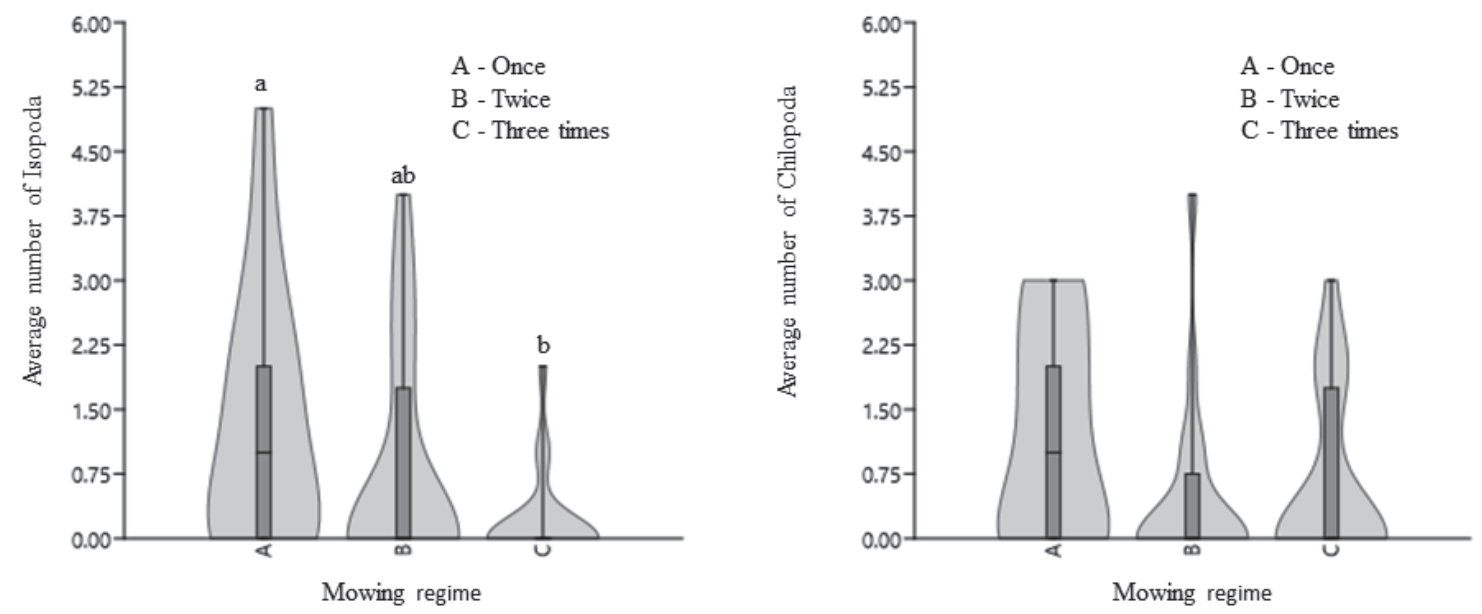

Fig. 2. Number of Isopoda and Chilopoda individuals with mowing regimes. Values followed by the same letter are not significantly different as determined by the Dunn test $(\mathrm{P}<0.05)$. Boxplots represent: median (horizontal line), interquartile range (box), minimum and maximum (vertical line), while the violins represent kernel density plot. 


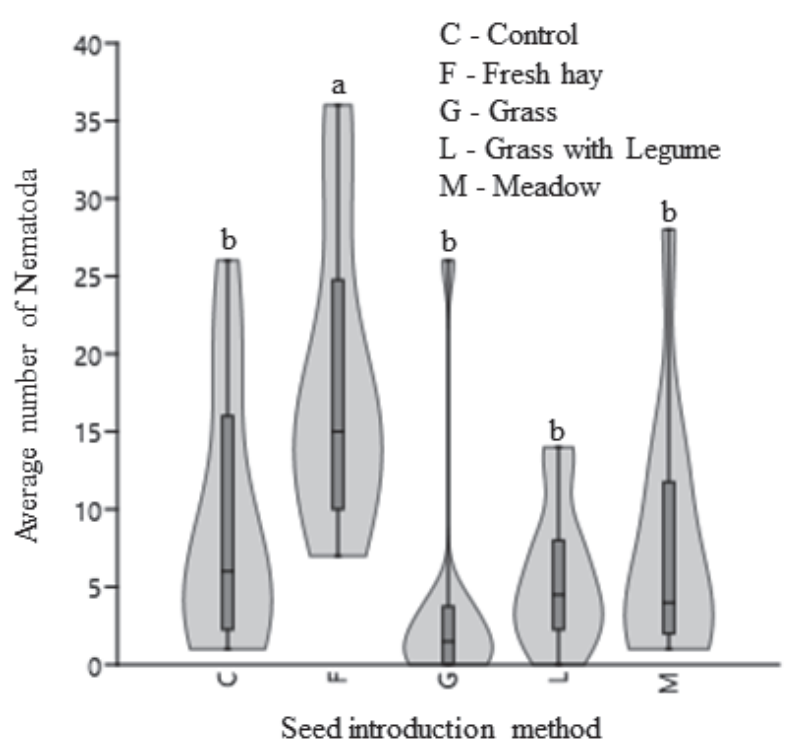

Fig. 3. Number of Nematoda responses to seed introduction methods. Values followed by the same letter are not significantly different as determined by the Dunn test $(\mathrm{P}<0.05)$. Boxplots represent: median (horizontal line), interquartile range (box), minimum and maximum (vertical line), while the violins represent kernel density plot.

evaluates the traits of all sampled arthropods according to their specialization to edaphic life, also indicated a similar trend. Therefore, the QBS-ar index seems more sensitive in the evaluation of soil quality in comparison to soil arthropods abundance itself. The mean value of QBS-ar was similar to values obtained by other authors [26-27]. For instance, the QBS-ar index calculated for post-mining areas varied from 40 to 140, and increased with the succession stage [26]. Mowing regimes change plant species composition. In the study of Józefowska et al. [28], mowing positively affected soil properties and enchytraeids abundance. Considering mowing frequency, it did not change the conservation value of seminatural grasslands [29]. In our study, frequent mowing negatively affected soil fauna. Gruss et al. [30] and Twardowski et al. [31], found negative effects of too frequent grazing on soil as well as epigeal fauna, which was explained by disturbance caused by cattle trampling. In the case of mowing, the explanation could be the changes in plant coverage, which have not yet been studied in this experiment.

Plant diversity is an important driver of soil biota abundance [32]. In our experiment we found significant effects of applying different methods of seed introduction and seed composition restoration on nematodes. The greatest abundance of this group was noticed in the stand where fresh hay was applied. This treatment has the greatest plant species richness (47 species). This is in line with the studies of other authors. In meta-analyses, increasing plant species richness positively affected decomposer activity, which is related with soil fauna abundance [33]. Birkhofer et al. [34] stated for example that the presence of legumes in the plant mixture positively affects soil biota.

The main findings of these preliminary studies are:

1. Mowing 3 times and 2 times per season negatively affected the abundance of Chilopoda and Isopoda in comparison to mowing once.

2. Introduction of fresh hay used in grassland restoration positively affected nematodes in comparison to the Solidago-dominated stand, and other seed introduction methods and seed composition treatments.

3. The biological soil quality index based on arthropods (QBS-ar) indicated a decrease of soil biological

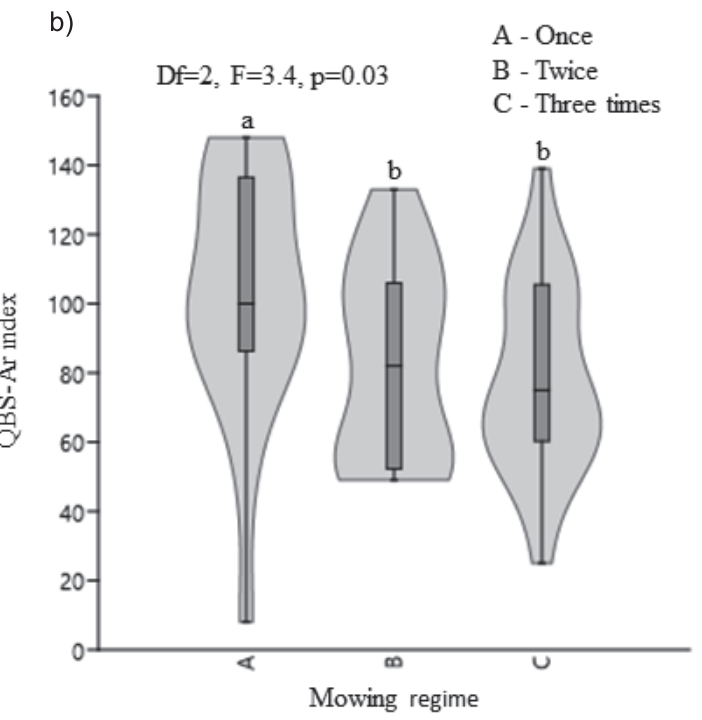

Fig. 4. Effects of seed introduction method a) and mowing times b) on QBS-ar index. Values followed by the same letter are not significantly different as determined by the Dunn test $(\mathrm{P}<0.05)$. Boxplots represent: median (horizontal line), interquartile range (box), minimum and maximum (vertical line), while the violins represent kernel density plot. 
quality in stands mown 2 and 3 times in comparison to mowing once.

To conclude, we found that mowing once per year and fresh hay applied as a grassland restoration method were most beneficial for soil fauna. When planning strategies for the restoration of Solidagoinvaded land, it is important to take into account the impact on belowground diversity of soil mesofauna. Further observations are needed to check their dynamics and taxonomic structure during subsequent years.

\section{Acknowledgments}

The authors would like to thank Hassanali Mollashahi (a PhD Student from Wroclaw University of Environmental and Life Sciences) for help with invertebrate counting, and Tomasz Szymura (University of Wroclaw) for his valuable contribution in the planning and establishment of the experiment.

\section{Conflicts of Interest}

The authors declare no conflicts of interest.

\section{Funding Declaration}

The study was supported by the 'UPWR 2.0:international and interdisciplinary programme of development of Wrocław University of Environmental and Life Sciences', co-financed by the European Social Fund under the Operational Programme Knowledge Education Development, under contract No. POWR.03.05.00-00-Z062/18 of 4 June 2019, Wrocław University of Environmental and Life Sciences (Poland) under the $\mathrm{PhD}$ research programme 'Doctoral student grant at the Doctoral School of Wrockaw University of Environmental and Life Sciences', and co-financed under the Leading Research Groups support project from the subsidy increased for the period 2020-2025 in the amount of $2 \%$ of the subsidy referred to in Art. 387 (3) of the Law of 20 July 2018 on Higher Education and Science, obtained in 2019.

\section{References}

1. WARDLE D.A., PELTZER D.A. Impacts of invasive biota in forest ecosystems in an aboveground-belowground context. Biological Invasions, 19, 3301, 2017.

2. VAN HENGSTUM T., HOOFTMAN D.A.P., OOSTERMEIJER J.G.B., VAN TIENDEREN P.H. Impact of plant invasions on local arthropod communities: a metaanalysis. Journal of Ecology, 102, 4, 2014.

3. SZYMURA M., SZYMURA T.H. Growth, phenology, and biomass allocation of alien Solidago species in central Europe. Plant Species Biology, 30, 245, 2015.
4. CHMURA D., DYBA P., KRAJ P., PEPLIŃSKA N., PILORZ A., ROMAN M. Invasion of Alien Solidago Taxa into Urban Habitats: A Study of Selected Towns in Southern Poland, Chemistry-Didactics-EcologyMetrology, 20, 97, 2016.

5. YE X.Q., YAN Y.N., MING W., YU F.H. High capacity of nutrient accumulation by invasive Solidago canadensis in a coastal grassland, Frontiers in Plant Science, 10, 1, 2019.

6. FENESI A., VÁGÁSI C.I., BELDEAN M., FÖLDESI R., KOLCSÁR L.P., SHAPIRO J.T., TÖRÖK E., KOVÁCSHOSTYÁNSZKI A. Solidago canadensis impacts on native plant and pollinator communities in different-aged old fields. Basic and Applied Ecology, 16, 335, 2015.

7. BARANOVÁ B., MANKO P., JÁSZAY T. Differences in surface-dwelling beetles of grasslands invaded and noninvaded by goldenrods (Solidago canadensis, S. gigantea) with special reference to Carabidae. Journal of Insect Conservation, 18, 623, 2014.

8. STERZYŃSKA M., SHRUBOVYCH J., NICIA P. Impact of plant invasion (Solidago gigantea L.) on soil mesofauna in a riparian wet meadows. Pedobiologia, 64, 1, 2017.

9. ČEREVKOVÁ A., MIKLISOVÁ D., BOBUL'SKÁ L., RENČO M. Impact of the invasive plant Solidago gigantea on soil nematodes in a semi-natural grassland and a temperate broadleaved mixed forest. Journal of Helminthology, 94, 1, 2020.

10. KLIMEK B., JAŹWA M., GOŁĘBIEWSKI M., SIKORA M., DEJA-SIKORA E. No apparent effect of invasive alien goldenrod on soil microbial communities or soil fauna feeding activity. Acta Oecologica, 109, 103669, 2020.

11. BRIONES M.J.I. Soil fauna and soil functions. Frontiers in Environmental Science, 2, 1, 2014.

12. CULLINEY T.W. Role of arthropods in maintaining soil fertility. Agriculture, 3, 629, 2013.

13. SANTORUFO L., VAN GESTEL C. A. M., ROCCO A., MAISTO G. Soil invertebrates as bioindicators of urban soil quality. Environmental Pollution, 161, 57, 2012.

14. PONGE J.F., PÉRÈS G., GUERNION M., RUIZCAMACHO N., CORTET J., PERNIND C., VILLENAVEE C., CHAUSSOD R., MARTIN-LAURENT F., BISPO A., CLUZEAU D. The impact of agricultural practices on soil biota: A regional study. Soil Biology and Biochemistry, 67, 271, 2013.

15. BIRKHOFER K., ADDISON M.F., ARVIDSSON F., BAZELET C., BENGTSSON J., BOOYSEN R., CONLONG D., HADDAD C, JANION-SCHEEPERS C., KAPP C., LINDBORG R., LOUW S., MALAN A.P., STOREY S.G., SWART W.J., ADDISO P. Effects of Ground Cover Management on Biotic Communities, Ecosystem Services and Disservices in Organic Deciduous Fruit Orchards in South Africa. Frontiers in Sustainable Food Systems, 3, 1, 2019.

16. WEIDLICH E.W.A., FLÓRIDO F.G., SORRINI T.B., BRANCALION P.H.S. Controlling invasive plant species in ecological restoration: A global review. Journal of Applied Ecology, 57, 1806, 2020.

17. ŚWIERSZCZ S., SZYMURA M., WOLSKI K., SZYMURA T.H. Comparison of methods for restoring meadows invaded by Solidago species. Polish Journal of Environmental Studies, 26, 1251, 2017.

18. NAGY D.U., RAUSCHERT E.S.J., HENN T, CIANFAGLIONE K., STRANCZINGER S., PAL R.W. The more we do, the less we gain? Balancing effort and efficacy in managing the Solidago gigantea invasion. Weed Research, 60, 232, 2020. 
19. PARISI V., MENTA C., GARDI C., JACOMINI C., MOZZANICA E. Microarthropod communities as a tool to assess soil quality and biodiversity: a new approach in Italy. Agricultural, Ecosystems and Environment, 105, 323, 2005.

20. DUNN O.J. Multiple comparisons using rank sums. Technometrics, 6, 241, 1964.

21. RAI P.K., SINGH J.S. Invasive alien plant species: Their impact on environment, ecosystem services and human health. Ecological Indicators, 111, 106020, 2020.

22. D'ANTONIO C., FLORY S.L. Long-term dynamics and impacts of plant invasions. Journal of Ecology, 105, 1459, 2017.

23. LITT A.R., CORD E.E., FULBRIGHT T.E., SCHUSTER G.L. Effects of invasive plants on arthropods. Conservation Biology, 28, 1532, 2014.

24. TÄLlE M., BALÁZS D., POSCHLOD P., VALKÓ O. Grazing vs. mowing: A meta-analysis of biodiversity benefits for grassland managements. Agriculture, Ecosystems and Environment, 222, 200, 2016.

25. REIS B.P., KÖVENDI-JAKÓ A., SZITÁR K., TÖRÖK K., HALASSY M. Long-term effect of mowing on the restoration of Pannonian sand grassland to replace invasive black locust plantation. Restoration Ecology, 1, 13152, 2020.

26. MADEJ G., BARCZYK G., GDAWIEC M. Evaluation of Soil Biological Quality Index (QBS-ar): Its Sensitivity and Usefulness in the Post-Mining Chronosequence Preliminary Research. Polish Journal of Environmental Studies, 20, 1367, 2011.

27. MENTA C., CONTI F.D., PINTO S., BODINI A. Soil Biological Quality index (QBS-ar): 15 years of application at global scale, Ecological Indicators, 85, 773, 2018.
28. JÓZEFOWSKA A., ZALESKI T., ZARZYCKI J., FRACCZEK K. Do mowing regimes affect plant and soil biological activity in the mountain meadows of Southern Poland? Journal of Mountain Science, 15, 2409, 2018.

29. TÄLlE M., DEÁK B., POSCHLOD P., VALKÓ O., WESTERBERG L., MILBERG P. Similar effects of different mowing frequencies on the conservation value of semi-natural grasslands in Europe. Biodiversity and Conservation, 27, 2451, 2018.

30. GRUSS I., PASTUSZKO K., TWARDOWSKI J., HUREJ M. Effects of different management practices of organic uphill grasslands on the abundance and diversity of soil mesofauna. Journal of Plant Protection Research, 58, 372, 2018.

31. TWARDOWSKI J., PASTUSZKO K., HUREJ M., GRUSS I. Effect of different management practices on ground beetle (Coleoptera: Carabidae) assemblages of uphill grasslands. Polish Journal of Ecology, 65, 400, 2017.

32. BENNET J.A., KOCH A.M., FORSYTHE J., JOHNSON N.C., TILMAN D., KLIRONOMOS J. Resistance of soil biota and plant growth to disturbance increases with plant diversity. Ecology Letters, 23, 119, 2020.

33. CHEN C., CHEN H.Y.H., CHEN X., HUANG Z. Meta-analysis shows positive effects of plant diversity on microbial biomass and respiration. Nature Communications. 10, 1332, 2019.

34. BIRKHOFER K., DIEKÖTTER T., BOCH S., FISCHER M., MÜLLER J., SOCHER S., WOLTERS V. Soil fauna feeding activity in temperate grassland soils increases with legume and grass species richness. Soil Biology and Biochemistry, 43, 2200, 2011.

\section{Supplementary Material}

Table S1. Plant species composition in seed mixtures and fresh hay used for grassland restoration in the experiment.

\begin{tabular}{|c|c|}
\hline Treatment & Plant species \\
\hline $\begin{array}{c}\text { Meadow seed } \\
\text { mixture } \\
(37 \text { species })\end{array}$ & $\begin{array}{l}\text { Achillea millefolium, Anthriscus sylvestris, Centaurea cyanus, C. jacea, Festuca pratensis, Daucus carota, } \\
\text { Galium album, G. wirtgenii, Heracleum sphondylium, Knautia arvensis, Leontodon hispidus, Leucanthemum } \\
\text { ircutianum/vulgare, Lotus corniculatus, Lychnis flos-cuculi, Papaver rhoeas, Plantago lanceolata, Prunella } \\
\text { vulgaris, Anthoxanthum odoratum, Sanguisorba officinalis, Scorzoneroides autumnalis, Silene dioica, Silene } \\
\text { vulgaris, Tragopogon pratensis, Trifolium pratense, Agrostis capillaris, Alopecurus pratensis, Rumex acetosa, } \\
\text { Arrhenatherum elatius, Bromus hordeaceus, Cynosurus cristatus, Dactylis glomerata, Helictotrichon } \\
\text { pubescens, Festuca rubra, Crepis biennis, Lolium perenne, Poa angustifolia, Trisetum flavescens }\end{array}$ \\
\hline $\begin{array}{l}\text { Grass seeds } \\
\text { (4 species) }\end{array}$ & Poa pratensis, Lolium perenne, Festuca pratensis, Phleum pratense \\
\hline $\begin{array}{c}\text { Grasses with legumes } \\
\text { (6 species) }\end{array}$ & Poa pratensis, Lolium perenne, Festuca pratensis, Phleum pratense, Trifolium repens, T. pratense \\
\hline $\begin{array}{l}\text { Fresh hay } \\
\text { (47 species) }\end{array}$ & $\begin{array}{l}\text { Achillea millefolium, Agrostis capillaris, Alchemilla monticola, Alopecurus pratensis, Veronica chamaedrys, } \\
\text { Arrhenatherum elatius, Centaurea jacea, Festuca rubra, Dactylis glomerata, Dianthus deltoides, Festuca } \\
\text { pratensis, Chaerophyllum aromaticum, Lotus corniculatus, Holcus lanatus, Hypericum maculatum, Knautia } \\
\text { arvensis, Lathyrus pratensis, Leucanthemum vulgare, Lolium perenne, Heracleum sphondylium, Phleum } \\
\text { pratense, Plantago lanceolata, Poa pratensis, Ranunculus acris, R. repens, Rumex acetosa, Senecio jacobaea, } \\
\text { Stellaria graminea, Tragopogon pratensis, Trifolium pratense, T. repens, Anthoxanthum odoratum, Vicia } \\
\text { cracca, V. hirsuta, V. sepium, Anthriscus sylvestris, Cerastium fontanum ssp. triviale, Taraxacum officinale, } \\
\text { Trisetum flavescens, Campanula patula, Pimpinella saxifraga, Elymus repens, Solidago virgaurea, Galium } \\
\text { mollugo, Lychnis flos-cuculi, Aegopodium podagraria, Geum urbanum }\end{array}$ \\
\hline
\end{tabular}


Table S2. Soil animal abundance and EMI scores assigned to the taxa.

\begin{tabular}{|c|c|c|c|c|c|c|}
\hline & Taxa & & No. individuals & Relative abundance (\%) & No. samples & EMI scores \\
\hline & & Formicidae (A) & 51 & 0.44 & 4 & 5 \\
\hline & & $\begin{array}{l}\text { Other Hymenopte- } \\
\operatorname{ra~(A)}\end{array}$ & 17 & 0.14 & 12 & 1 \\
\hline & & Hymenoptera (L) & 1 & 0.01 & 1 & 10 \\
\hline & & Coleoptera (A) & 29 & 0.24 & 19 & 5 \\
\hline & Insecta & Coleoptera (L) & 67 & 0.57 & 35 & 5 \\
\hline & & Diptera (A) & 11 & 0.09 & 5 & 1 \\
\hline & & Diptera (L) & 93 & 0.79 & 36 & 10 \\
\hline & & Thysanoptera (A) & 2 & 0.01 & 2 & 1 \\
\hline Arthropoda & & Lepidoptera (L) & 3 & 0.03 & 3 & 10 \\
\hline & & Collembola & 7967 & 67.37 & 60 & $1-20 * *$ \\
\hline & 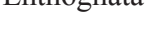 & Diplura & 1 & 0.01 & 1 & 20 \\
\hline & & Symphyla & 81 & 0.68 & 32 & 10 \\
\hline & Myriapoda & Chilopoda & 45 & 0.38 & 23 & 20 \\
\hline & & Diplopoda & 19 & 0.16 & 17 & 20 \\
\hline & Crustacea & Isopoda & 46 & 0.40 & 21 & 10 \\
\hline & & Acari & 2750 & 23.26 & 58 & 20 \\
\hline & & Aranae & 11 & 0.09 & 9 & 5 \\
\hline & Nemato & & 523 & 4.42 & 55 & - \\
\hline & lida & Lumbricidae & 20 & 0.17 & 8 & - \\
\hline & Total & & 11825 & 100.0 & & \\
\hline
\end{tabular}

*A - adults, L - larvae

**There are 7 levels of EMI scores for Collembola (from 1 to 20), which depend on several traits. For instance, epigeic Collembola get 1,2 , or 4 scores, while euedaphic Collembola get 10 or 20 scores. 